\title{
Karakterisasi Contoh Spontan Guru Pemula Dalam Pembelajaran Matematika
}

\author{
Selly Meinda Dwi Cahyaningsih ${ }^{1}$, Subanji ${ }^{1}$, I Made Sulandra ${ }^{1}$ \\ ${ }^{1}$ Pendidikan Matematika-Universitas Negeri Malang
}

\begin{tabular}{l} 
INFO ARTIKEL \\
\hline Riwayat Artikel: \\
Diterima: 08-05-2019 \\
Disetujui: $16-12-2019$ \\
\hline
\end{tabular}

Kata kunci:

beginner teacher; spontaneous example; mathematics learning; guru pemula; contoh spontan; pembelajaran matematika

\author{
Alamat Korespondensi: \\ Selly Meinda Dwi Cahyaningsih \\ Pendidikan Matematika \\ Universitas Negeri Malang \\ Jalan Semarang 5 Malang \\ E-mail: sellymeinda21@gmail.com
}

\begin{abstract}
ABSTRAK
Abstract: The purpose this study is to explore characterization of teacher's spontaneous example. Type a study is deskriptif kualitatif, subject is beginner teacher. The results show that three spontaneous examples characterization of beginner teacher such that illustrative spontaneous examples, clarified spontaneous examples, and confirmatory spontaneous examples. Illustrative spontaneous examples is given beginner teacher to illustrate students difficulty and explaned the new topic. Clarified spontaneous examples is given beginner teacher to clarified students difficulty and students error. Confirmatory spontaneous examples is given beginner teacher to confirm mathematics concept and understanding of students contents.
\end{abstract}

\begin{abstract}
Abstrak: Penelitian ini bertujuan untuk mengeksplorasi karakterisasi contoh spontan guru dalam pembelajaran matematika. Jenis penelitian yang digunakan yaitu kualitatif deskriptif, dengan subjek penelitian guru matematika pemula. Hasil penelitian menunjukan bahwa tiga karakterisasi contoh spontan guru pemula yaitu contoh spontan ilustratif, contoh spontan klarifikatif dan contoh spontan konfirmatif. Contoh spontan ilustratif diberikan guru pemula untuk mengilustrasikan masalah kesulitan yang dialami siswa. Contoh spontan klarifikatif diberikan guru pemula untuk mengklarifikasi kesalahan siswa. Contoh spontan konfirmatif diberikan guru pemula untuk mengonfirmasi bahwa siswa telah memahami materi yang dibahas.
\end{abstract}

Siswa mengeluhkan bahwa aljabar itu sulit (Lian, 2016) oleh karenanya banyak kesalahan yang dilakukan siswa dalam belajar aljabar, hal ini didasari pada lemahnya pemahaman konsep aljabar siswa (Sitrava, 2017). Beberapa kelemahan pemahaman konsep aljabar siswa diantaranya conjoining operasi penjumlahan dan perkalian, kesalahan dalam melakukan representasi dan interpretasi terhadap informasi yang disajikan pada soal cerita dan kesalahan ekstrapolasi linear (Sitrava, 2017; Herutomo \& Saputro, 2014; Mulungye \& Ndethiu, 2016). Secara khusus aljabar yang dikeluhkan sulit pada siswa SMP kelas VIII yaitu Sistem Persamaan Linear Dua Variabel (SPLDV), ini sesuai yang diungkapkan oleh guru karena dalam belajar SPLDV siswa harus benar-benar memahami materi matematika yang lainya. Seperti aljabar satu variabel, operasi aljabar dengan koefisien bilangan bulat maupun pecahan, menggambar grafik serta himpunan penyelesaiannya, dan siswa harus dapat memahami masalah soal cerita.

Salah satu cara yang dapat dilakukan guru untuk membantu siswa mengatasi pemahaman konsep atau prosedur matematika yaitu dengan memberikan contoh dalam belajar matematika. Contoh sangat penting dalam mengatasi kesulitan siswa dalam belajar aljabar (Zaslavsky, 2010). Pemberian contoh pada siswa juga membantu siswa memecahkan latihan dan masalah matematika (Irawan, 2015; Weber, dkk., 2011; Zazkis, \& Chernoff, 2008). Pemahaman siswa tentang ide matematika tergantung pada contoh yang digunakan oleh guru saat mengajar (Huang, 2017). Penggunaan contoh dalam pembelajaran matematika juga untuk menggambarkan prinsip dan pola materi yang dipelajari (Atkinson, dkk., 2000). Pemberian contoh yang dilakukan guru tidak serta merta berasal dari keinginan guru dalam memberikan contoh di kelas atau yang telah disusun guru dalam rencana pelaksanaan pembelajaran. Guru harus dapat menyesuaikan bagaimana contoh yang digunakan untuk membuat siswa lebih memahami konsep maupun penyelesaian masalah. Kegiatan pembelajaran di kelas pasti menghasilkan hubungan imbal balik antara guru dengan siswa, bagaimana siswa merespons pelajaran yang diberikan guru juga sebaliknya. Peristiwa-peristiwa ini sering kali meningkatkan kebutuhan bagi guru untuk merespon langsung dan menemukan contoh yang tepat untuk menjawab kebutuhan yang dimunculkan siswa (Zodik \& Zaslavsky, 2008).

Contoh yang tidak direncanakan, dikontruksi, dibuat secara baru dan langsung oleh guru atau dimodifikasi, dikembangkan dari contoh-contoh yang telah digunakan oleh guru di kelas disebut dengan contoh spontan (Zodik \& Zaslavsky, 2008). Contoh spontan juga merupakan upaya dalam meningkatkan kreativitas guru dalam pembelajaran matematika, yang akan dimanfaatkan untuk meningkatkan pemahamam konsep, prinsip dan prosedur matematika siswa dan menghasilkan ketercapaian 
tujuan pembelajaran matematika (Baharullah, 2016). Contoh spontan sangat membantu guru ketika merespons pertanyaan siswa yang sebelumnya tidak pernah guru rencanakan dalam RPP. Penggunaan contoh spontan dalam pembelajaran matematika di kelas merupakan bagian kelengkapan dari praktik pengajaran matematika dan memiliki pengaruh besar pada pembelajaran. Oleh karena itu, dalam penelitian ini dilakukan eksplorasi karakterisasi contoh spontan guru dalam belajar matematika materi aljabar kelas VIII SMP. Dengan karakterisasi contoh spontan yaitu contoh spontan ilustratif, contoh spontan klarifikatif dan contoh spontan konfirmatif.

\section{METODE}

Jenis penelitian ini adalah penelitian kualitatif deskriptif. Dengan tujuan untuk mengeksplorasi karakterisasi contoh spontan guru dalam pembelajaran matematika. Penelitian ini dilaksanakan di SMP Ar-Rohmah kelas VIII materi SPLDV. Subjek penelitian adalah guru matematika lulusan S1 pendidikan matematika dan masa kerja mengajarnya dua tahun. Pengambilan data dilakukan menggunakan handycame atau perekam video selama guru mengajar materi SPLDV di kelas. Instrumen yang digunakan adalah pedoman wawancara untuk lebih menggali informasi alasan pemberian contoh spontan oleh guru. Contoh spontan yang dimunculkan oleh guru ditentukan terlebih dahulu melalui video yang diambil saat proses pembelajaran berlangsung. Kemudian dilanjutkan dengan wawancara yang direkam dengan alat perekam, saat guru diwawancarai potongan rekaman video guru yang memunculkan contoh spontan diputar kembali untuk mengingatkan pembelajaran dan pemberian contoh oleh guru.

\section{HASIL}

Dari pengamatan yang telah dilaksanakan, guru memunculkan cukup banyak contoh spontan dalam pembelajaran SPLDV. Dikatakan contoh spontan karena contoh tersebut belum pernah digunakan dalam pembelajaran sebelumnya, tidak direncanakan dalam RPP dan tidak ada dalam buku pegangan siswa. Contoh spontan yang dimunculkan guru kemudian dikarakterisasi berdasarkan karakterisasi contoh spontan, yaitu contoh spontan ilustratif, spontan klarifikatif, dan spontan konfirmatif. Berikut masing-masing contoh spontan yang dimunculkan guru dan diungkap pertimbangan pemberian contoh spontan tersebut.

Guru pemula memberikan materi tentang persamaan linear dua variabel (PLDV). Ketika guru pemula menjelaskan materi titik potong grafik terhadap koordinat kartesius, guru menyampaikan "jika titik potongnya terhadap sumbu $x$, maka $y=0$, dan jika titik potong terhadap sumbu $y$, maka $x=0$ ". Ada siswa bertanya "itu pasti 0 ya?", pertanyaan siswa tersebut meyakinkan pemahamannya tentang nilai 0 pada $x$ untuk mencari titik potong pada sumbu $y$ dan nilai 0 pada y untuk mencari titik potong pada sumbu $x$. Guru pemula memberikan contoh PLDV menentukan titik potong pada sumbu koordinat kartesius yang telah dibahas di buku siswa. Setelah menentukan nilai titik potong pada sumbu $x$ dan sumbu $y$, tidak ada siswa yang menanggapi atau bertanya lagi. Guru pemula kemudian memberikan contoh spontan PLDV $x+2 y=4$ dan meminta siswa menentukan titik potong pada sumbu $x$ dan sumbu $y$, dengan tujuan untuk mengonfirmasi atau menegaskan bahwa siswa telah memahami cara menentukan titik potong pada sumbu $x$ atau sumbu $y$. Contoh spontan tersebut merupakan contoh yang melalui proses konfirmasi.

Setelah pemberian contoh baru oleh guru pemula selesai dibahas bersama, kemudian ada siswa (S1) mengungkapkan pernyataan bahwa ia bingung dalam menentukan nilai 0 . Untuk merespon pernyataan S1 guru pemula memberikan pertanyaan pada S1 sebagai penjelasan, meletakkan 0 pada $y$ untuk menentukan titik potong sumbu $x$ dan meletekan 0 pada $x$ untuk menentukan titik potong sumbu $y$. Kemudian guru pemula memberikan contoh baru berupa PLDV $4 x-8 y=16$ lagi yang tidak jauh berbeda dengan persamaan linear dua variabel yang sebelumnya sudah dikerjakan bersama. Terlihat bahwa penggunaan contoh spontan tersebut sebagai penjelasan tambahan yang digunakan guru, agar membantu siswa memahami konsep perpotongan pada sumbu $x$ dan sumbu $y$, dalam contoh ini guru juga menggunakan bilangan yang sederhana. Sehingga contoh spontan ini melalui proses ilustrasi. Berikut pemaparan percakapan guru pemula (GP) dan S1 di kelas.

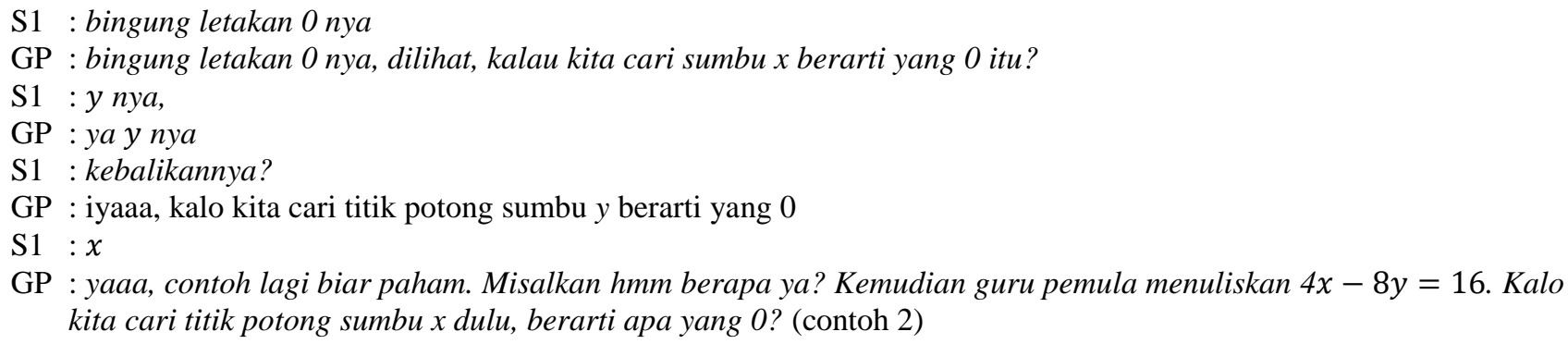

Guru pemula membuat 2 contoh spontan PLDV yang berbeda yaitu $x-2 y=4$ dan $4 x-8 y=16$. Pertimbangan guru pemula dalam memberikan contoh tersebut yaitu membuat siswa lebih mengerti tentang perpotongan pada sumbu $x$ dan sumbu $y$. Seperti yang guru pemula terangkan dalam wawancara "kalau hanya diberikan satu contoh saja yang ada di buku, siswa akan mengetahui yang hanya ada di situ. Sehingga saya berinisiatif, untuk memberi contoh tambahan lagi. Kekhawatiran saya jika 
menjelaskan dengan contoh yang ada di buku, saya tidak akan tau siswa benar-benar paham atau tidak, karena ketika dibahas berssama siswa akan merespon setiap langkah yang dikerjakan di papan tulis sesuai dengan yang ada di buku".

Setelah contoh PLDV baru selesai dibahas bersama, selanjutnya siswa (S2) bertanya. Dari pertanyaan tersebut S2 memastikan kebenaran pemahamannya tentang titik potong dengan sumbu koordinat. Untuk menentukan titik potong pada sumbu koordinat maka nilai $x$ atau $y$ harus dimisalkan bernilai 0 . Karena jika mencari titik potong pada sumbu $x$ maka $y=0$ dan jika mencari titik potong pada sumbu $y$ maka $x=0$. Guru pemula menjawab pertanyaan siswa secara langsung, dengan menggambar grafik dan menunjukkan secara langsung titik yang berpotongan pada sumbu $x$ dan sumbu $y$. Guru pemula memberikan penjelasan dengan grafik agar terlihat jelas letak titik potong, sehingga siswa paham dengan $x=0$ saat titik tersebut di sumbu $y$ dan $y=0$ saat titik tersebut di sumbu $x$. Guru pemula menjelaskan dalam wawancara pertimbangan guru pemula dalam memberikan contoh tersebut yaitu "kalau hanya menyampaikan secara verbal siswa pasti hanya membayangkan saja dan membayangkan itu belum tentu persepsinya sama. Jadi mungkin secara visual kalo digambarkan seperti itu bisa lebih paham dan kalau misalnya langsung digambarkan seperti itu juga, dapat lebih jelas menunjukan titik yang berpotongan dengan sumbu koordinat". Contoh spontan tersebut melalui proses klarifikasi, dan berikut pemaparan pertanyaan S2 yang direspons guru pemula menggunakan contoh dengan gambar.

S2 : harus 0 ya?

GP : ini titik potong kan. Kalo kita mencari titik potong, misalnya ya ada grafik fungsi seperti ini,

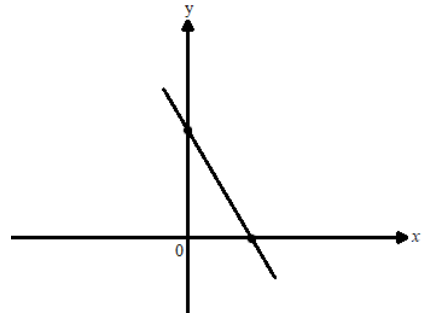

\section{Gambar 1. Contoh Perpotongan Sumbu Koordinat}

dia punya titik potong sumbu y disini (menunjuk titik potong pada sumbu y) dan titik potong sumbu $x$ disini (menunjuk titik potong pada sumbu $\mathrm{x}$ ) berarti kan dia temannya itu 0, kalo dia nempel di sumbu koordinat berarti salah satunya $0 . \underline{(\operatorname{contoh} 3)}$

Siswa diminta guru pemula untuk menyelesaikan soal-soal latihan yang ada di buku siswa. Pada perintah soal nomor satu, siswa diminta mengubah soal cerita menjadi persamaan linear dua variabelnya. Karena sebelumnya guru pemula belum memberikan materi untuk mengubah soal cerita menjadi persamaan linear dua variabelnya, guru pemula memberikan contoh langsung dengan masalah kontekstual. Guru pemula menerangkan penggunaan contoh seperti itu dengan pertimbangan "karena ini merupakan soal cerita, sehingga digunakan contoh yang kontekstual, lebih ke sehari-hari siswa seperti apa. Beras dan telur kebutuhan yang siswa paham bentuk rupanya, sehingga mengerti dan memudahkan siswa membayangkannya. Dari masalah yang kontekstual dapat membuat siswa lebih paham dalam memodelkan matematika masalah tersebut". Contoh soal cerita tersebut merupakan contoh spontan dan melalui proses ilustrasi. Guru pemula mengilustrasikan cara mengubah persamaan linear dua variabel dari masalah kontekstual. Berikut pemaparan percakapan guru pemula, semua siswa yang merespons (S) dan siswa (S3) yang bertanya.

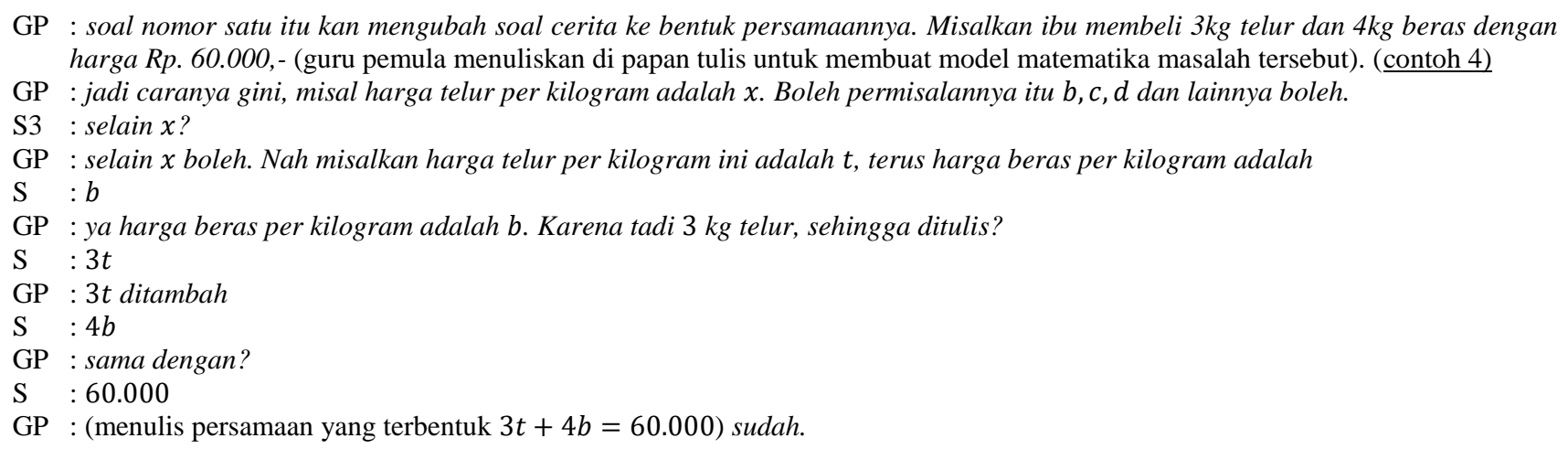

Permasalahan selanjutnya saat siswa mengerjakan soal latihan, seorang siswa (S4) bertanya pada guru pemula apakah latihan yang dikerjakannya benar atau salah. Kesalahan S4 terjadi saat mengoperasikan $-12=-3 y$, siswa menjawab $\frac{-12}{3}=y$ sehingga nilai $y=-4$, seperti pada gambar 2 . 


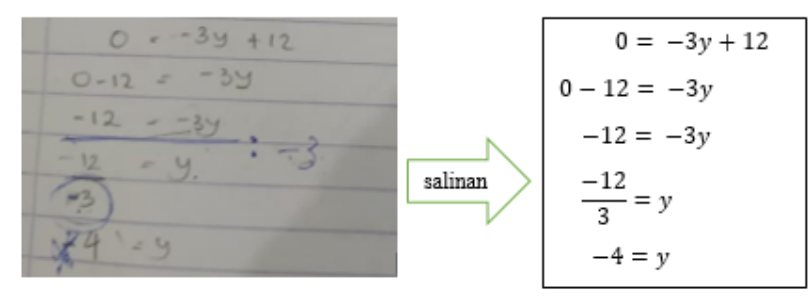

\section{Gambar 2. Kesalahan S4 dalam Menjawab Soal SPLDV}

Guru pemula langsung merespons dengan membuat contoh yaitu contoh $\frac{-1}{1}$, yang selanjutnya ditanyakan pada S4 berapa hasil dari pembagian tersebut. Guru pemula menjelaskan dalam wawancara penggunaan contoh tersebut "biar bilangan itu tidak berubah, maksudnya biar tetep satu harus dikali satu kan, lebih memperhatihan ke siswa untuk tau bagaimana cara mengubah negatif jadi postif, harus dikalikan atau dibagi berapa biar hasilnya tetap". Contoh tersebut melalui proses klarifikasi karena guru pemula memberi contoh tersebut mengklarifikasi bahwa pembagian bilangan negatif dengan positif menghasilkan negatif, sedangkan pembagian bilangan negatif dengan negatif menghasilkan positif. Contoh tersebut digunakan guru pemula untuk menggiring siswa mengerjakan latihan yang salah dikerjakan siswa yaitu menjadikan $y$ positif dari nilai sebelumnya $y$ negatif. Berikut percakapan penjelasan guru pemula melalui pertanyaan dengan contoh langsung.

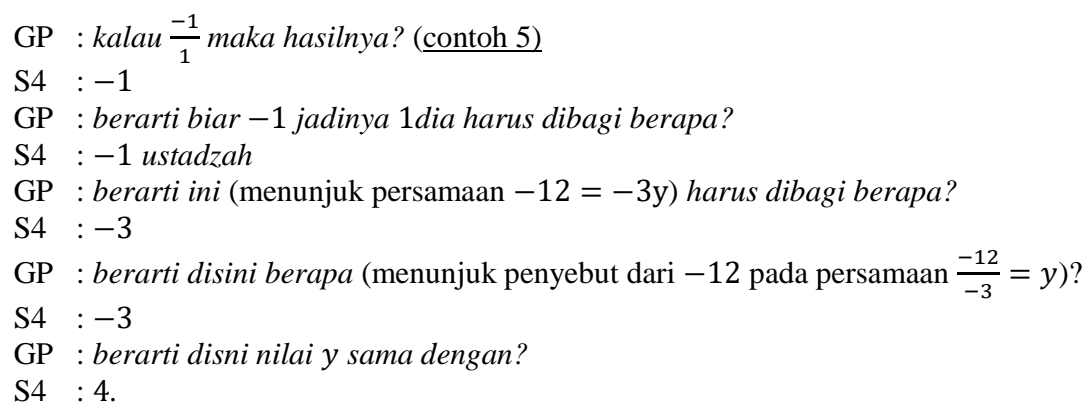

Guru pemula dan siswa membahas secara bersama-sama latihan soal. Siswa kesulitan saat menyelesaikan $x-y=1$ dengan $x=0$, sehingga menghasilkan $-y=1$. Guru pemula bertanya kepada siswa karena yang ditentukan nilai $y$, sehingga $-y$ pada $-y=1$ agar menjadi $y$ harus diapakan. Hampir seluruh siswa menjawab dengan benar, yaitu harus dikalikan -1 . Kemudian ada siswa (S5) kesulitan memahami dari mana nilai -1 tersebut. Guru pemula bertanya kembali kepada siswa, yang kemudian berlanjut dengan pemberian pertanyaan dengan contoh. Contoh yang diberikan guru pemula yaitu misalkan -1 dikali berapa biar hasilnya 1? Dari contoh tersebut guru pemula memberikan contoh menggunakan proses klarifikasi bahwa untuk menjadikan $y$ dari $-y$ kedua ruas perlu dikalikan -1 atau dalam contoh yang diberikan guru pemula yaitu -1 dikalikan berapa supaya menghasilkan 1. Guru pemula dalam wawancara mengatakan alasan pemberian contoh ini "yang kita butuhkan hanya $y$, contoh digunakan untuk menghasilkan tetap $y$ hanya berbeda tanda, menggunakan satu untuk pengalinya. Ini juga mempermudah siswa memahaminya". Berikut dipaparkan pertanyaan S5 dalam percakapan.

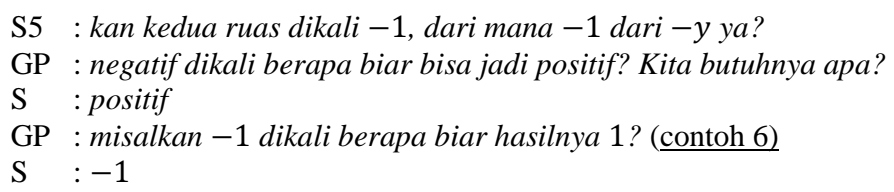

Selanjutnya, guru pemula mengembalikan pembahasan contoh pada tahap mengubah $-y$ menjadi $y$ dengan bertanya, ternyata respon siswa ada yang menjawab $-y$ dan -1 . Guru pemula langsung mengerjakan sesuai jawaban siswa yaitu $-y \times$ -1 dan $-y \times-y$. Contoh spontan tersebut melaui proses klarifikasi, untuk memberikan siswa penjelasan perbedaan hasil operasi perkalian $-y$ dan -1 sama dengan $y$, sedangkan operasi perkalian $-y$ dan $-y$ sama dengan $y^{2}$ atau perbedaan hasil kali antara perkalian variabel dan bilangan, juga hasil kali antara variabel dan variabel. Seperti pertimbangan guru pemula dalam memberikan contoh ini yaitu "karena respons siswa berbeda, sehingga saya harus menjelaskan bahwa hasil perkalian yang disebutkan siswa tersebut memiliki hasil yang berbeda". Berikut pemaparan percakapannya.

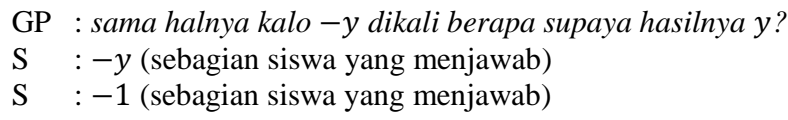




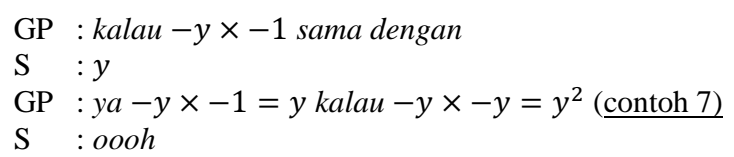

Metode subtitusi merupakan salah satu metode penyelesaian dari soal SPLDV. Saat guru pemula menjelaskan metode subtitusi, sebelum menggunakan contoh yang ada di buku, guru pemula membuat contoh sistem persamaan linear satu variabel yang diselesaikan bersama-sama. Guru pemula memberikan contoh langsung pada saat memberikan pembahasan baru karena terkadang guru pemula lupa dengan contoh yang ada di buku sehingga untuk memberikan gambaran materi yang akan disampaikannya sering sekali guru pemula membuat contoh-contoh spontan dan baru. Hal inilah yang dilakukan guru saat menjelaskan materi metode subtitusi. Guru pemula menjelaskan pemberian contoh spontan sistem persamaan linear satu variabel

$$
\left\{\begin{array}{c}
y=4 \\
y+5=9
\end{array}\right.
$$

karena bilangan yang digunakan kecil dan operasi penjumlahan sederhana. Contoh spontan ini melalui proses ilustrasi karena digunakan untuk memberikan gambaran sistem persamaan satu variabel dan mengenalkan pada siswa tentang metode subtitusi. Siswa (S6) yang bertanya pada guru pemula untuk memastikan pemahamannya tentang metode subtitusi. Berikut pemaparan percakapannya.

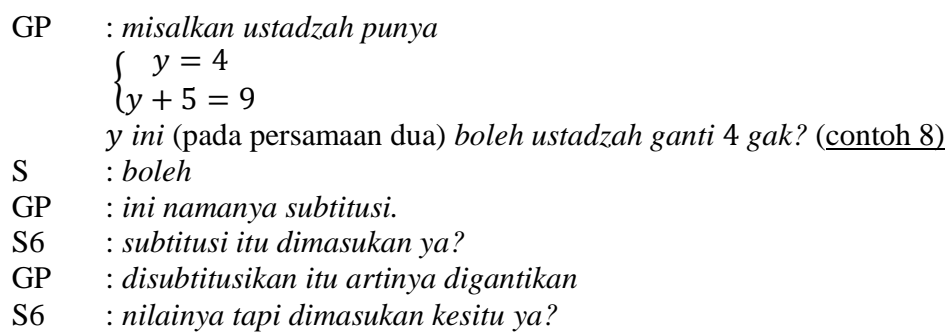

Akibat dari pertanyaan S6 pada percakapan di atas, guru pemula memberikan contoh kembali yang merupakan contoh SPLDV. Contoh SPLDV ini merupakan contoh yang mengonfirmasi respon siswa melalui proses ilustrasi dan proses klarifikasi. Pemberian SPLDV tersebut merupakan proses ilustrasi yang dilakukan guru pemula. Selanjutnya menyelesaikan SPLDV dengan metode subtitusi merupakan proses klarifikasi yang diberikan guru pemula akibat dari pertanyaan siswa tentang menyelesaikan sistem persamaan dengan metode subtitusi. Pertimbangan guru pemula dalam memunculkan contoh spontan yang kedua yaitu "memberikan gambaran tambahan dalam mengenalkan tentang metode subtitus pada siswa, juga sebagai respons atas pertanyaan siswa tentang metode subtitusi. Contoh kedua lebih rumit agar dalam contoh yang kedua sedikit lebih meningkat dalam memikirkan solusinya tapi cara pengerjaannya sama dengan contoh sebelumnya (metode subtitusi)". Berikut pemaparan percakapannya.

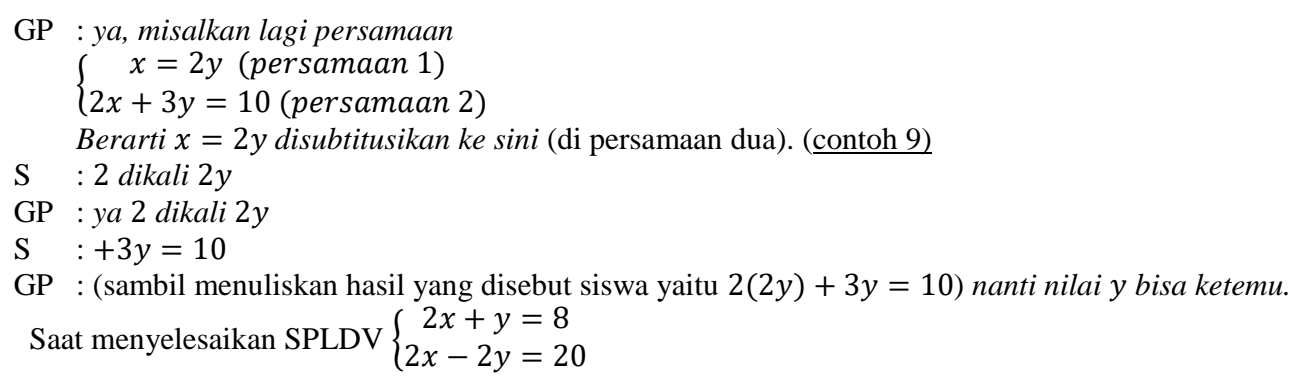

Guru pemula memberikan pertayaan pada siswa operasi apa yang akan digunakan untuk mengeliminasi variabel $x$. Siswa menjawab dengan melakukan operasi pengurangan. Namun ada siswa (S7) bingung dalam melakukan eliminasi variabel $x$ yang sudah memiliki koefisien sama, dan bertanya mengapa dilakukan operasi kurang. Kebingungan siswa diduga karena pada eliminasi pertama menggunakan operasi penjumlahan, sedangkan penyelesaian eliminasi kedua menggunakan operasi pengurangan. Guru pemula menjawab pertanyaan siswa berdasarkan letak kebingungan siswa melakukan operasi kurang, yang direspon siswa dengan mengingat kembali eliminasi pertama yang menggunakan operasi tambah. Selanjutnya guru pemula memberikan pertanyaan lagi yang merupakan contoh spontan, jika -1 dengan -1 agar menjadi 0 harus dilakukan operasi apa. Pertimbangan guru pemula menggunakan contoh tersebut yang terekam dalam wawancara yaitu "karena mungkin pakai nilai selain 1 siswa-siswa bingung dan kalau ada variabelnya pun siswa-siswa juga bingung, makanya terpikirkan menggunakan satu. Kalau pakai satu siswa sudah paham untuk operasi yang dilakukan dari nilai positif atau negatif bilangan yang dikurangi ataupun 
pengurangnya, baru di masukan ke dalam persamaan dengan variabelnya". Contoh tersebut merupakan proses klarifikasi yang dilakukan oleh guru pemula, dengan menyampaikan bahwa operasi yang dilakukan tergantung dari nilai positif atau negatif bilangan yang dikurangi ataupun pengurangnya. Berikut percakapan yang terjadi.

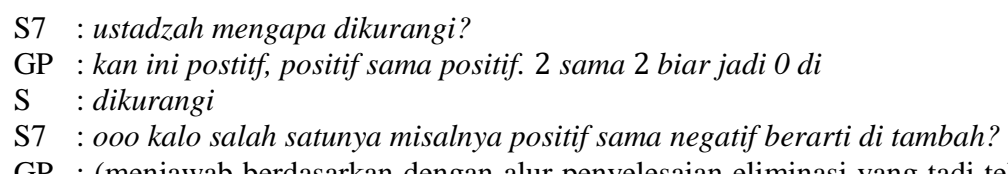

GP : (menjawab berdasarkan dengan alur penyelesaian eliminasi yang tadi telah diselesaikan bersama) harus dilihat dulu, dia kalau positif dengan positif maka dikurangi (menunjuk langkah eliminasi ke dua), kalau dia positif dengan negatif bagaimana caranya biar dia jadi 0 (menunjuk langkah eliminasi pertama). Misalkan -1 sama -1 biar bisa jadi 0, operasinya? (contoh 10)

$\mathrm{S} \quad$ : kurang (sebagian siswa menjawab)

$\mathrm{S} \quad$ : tambah (sebagian siswa menjawab)

GP : ya dikurangi (menulis $-1-(-1)$ ), berarti $-1+1$ sama dengan?

$\mathrm{S}:$ : nol

GP : berarti ini paham (menunjuk persamaan yang di eliminasi dengan pengurangan tadi)?

S : paham

Setelah menyelesaikan persamaan tersebut dan siswa telah paham dalam mengeliminasi variabel. Ada siswa (S8) bertanya pada tahapan penyelesaian SPLDV dengan metode eliminasi yaitu variabel yang akan dieliminasi harus memiliki koefisien sama. Sehingga untuk menyamakan koefisien variabel yang akan dieliminasi dalam persamaan-persamaan tersebut harus dikalikan dengan bilangan yang sesuai dengan koefisien pada variabel yang akan dieliminasi atau mencari KPK dari koefisien pada variabel yang akan dieliminasi. Siswa bingung bagaimana cara menyamakan koefisien variabel yang akan dieliminasi, sehingga guru pemula memberikan contoh SPLDV $\left\{\begin{array}{c}3 x-y=5 \\ 2 x+2 y=6\end{array}\right.$.

Pertimbangan guru pemula dalam memunculkan sistem persamaan yang baru yaitu "siswa-siswa mengerjakan dengan metode eliminasi juga baru, jadinya saya mikirnya ngasi persamaan yang sederhana. Itu kan koefisiennya cukup sederhana di siswa. Contoh baru tersebut digunakan agar siswa tidak bingung lagi dalam eliminasi, juga untuk melatih siswa agar berkembang pengetahuannya untuk menyelesaikan SPLDV dengan metode eliminasi. Tidak terpaku pada operasi bilangan positif dan negatif, tapi juga pada operasi bilangan negatif dan positif'. Contoh yang diberikan guru pemula tersebut menggunakan proses ilustrasi, karena digunakan guru pemula sebagai penjelasan tambahan untuk siswa lebih memahami cara menyamakan koefisien variabel yang akan dieliminasi. Berikut percakapan yang terjadi antara guru pemula dengan S8.

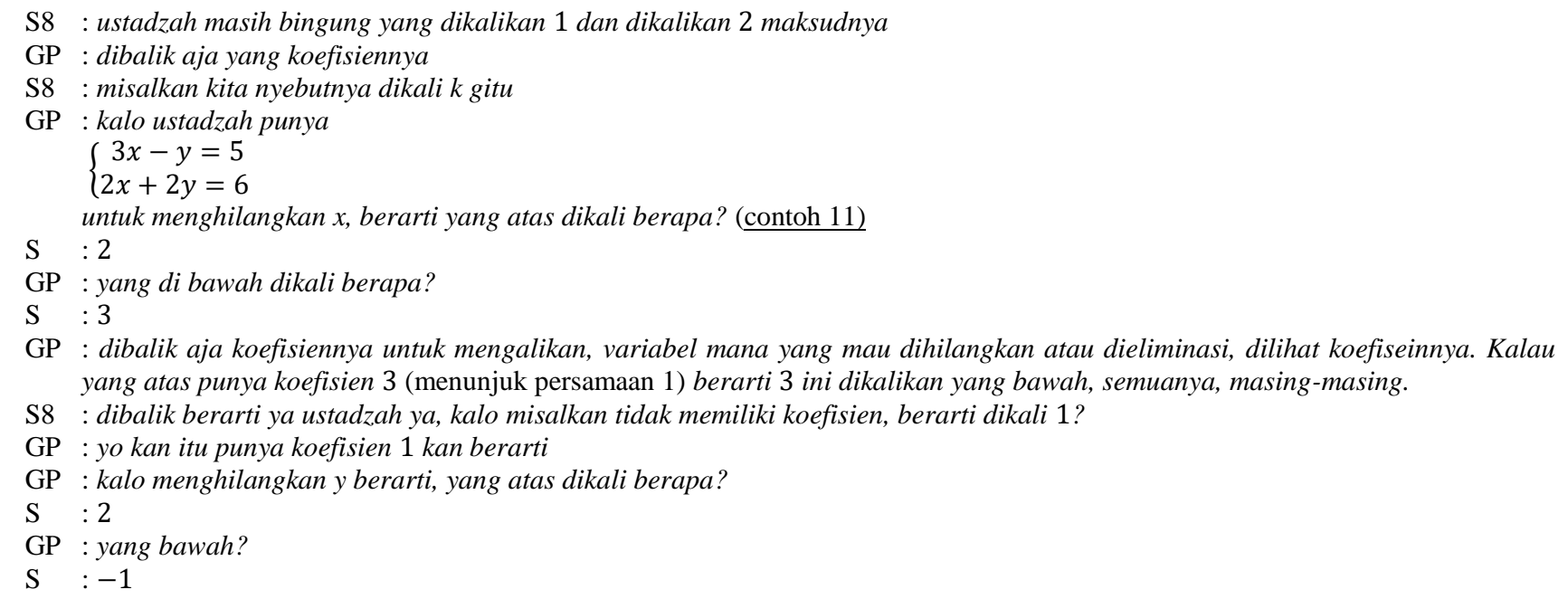

Saat guru pemula dan siswa menyelesaikan bersama-sama soal cerita SPLDV dengan metode subtitusi, masih ada siswa yaitu S9 yang keliru dalam melakukan subtitusi. Siswa tau subtitusi diartikan sebagai menggantikan, namun siswa bingung apa yang akan digantikan dalam menyelesaikan SPLDV. Sehingga guru pemula memberikan contoh, memisalkan sebuah persamaan dengan menggunakan warna, warna ungu dalam bahasa indonesia yang sama artinya dengan purple dalam bahasa inggris. Contoh ini merupakan contoh spontan yang menggunakan proses ilustrasi saat memisalkan dengan warna, dan menggunakan proses klarifikasi ketika guru pemula mencoba untuk menjelaskan subtitusi dari warna dalam kalimat. Alasan guru pemula menggunakan contoh ini, agar siswa paham secara nyata saat menyelesaikan persamaan dengan metode subtitusi dan menegaskan variabel yang digantikan. Berikut dipaparkan percakapan S9 saat bertanya di kelas. 


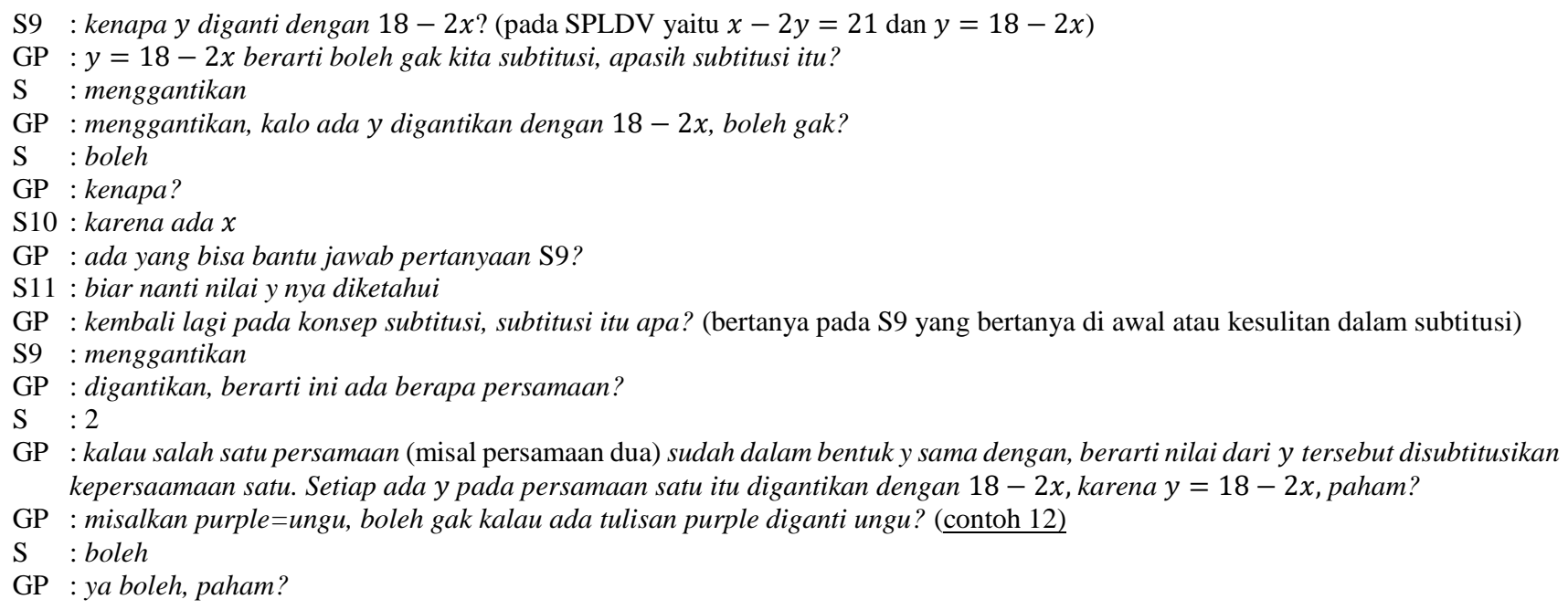

Tidak hanya itu saja, selanjutnya pemberian contoh spontan guru pemula tentang subtitusi menggunakan minyak kayu putih. Penjelasan kembali oleh guru pemula tentang metode subtitusi ini, tanpa ada pertanyaan dari siswa, guru pemula masih belum yakin siswanya sudah paham, sehingga munculah kembali contoh spontan ini. Contoh ini berujuan mengonfirmasi pemahaman siswa melalui proses ilustrasi dan proses klarifikasi. Proses ilustrasi saat guru pemula mencoba memberi contoh dengan minyak kayu putih, dan menggunakan proses klarifikasi ketika guru pemula mencoba untuk menjelaskan subtitusi dari nama merek minyak kayu putih dalam kalimat. Pertimbangan guru pemula memberi contoh minyak kayu putih agar siswa memahami dengan lebih baik menyelesaikan menggunakan metode subtitusi, sehingga digunakan masalah yang kontekstual.

GP : sama kalo misalnya minyak kayu putih, minyak kayu putih itu kan ada banyak macamnya, ada caplang ada gajah. Misalnya minyak kayu putih = caplang, boleh gak kita nyebutnya langsung caplang? Boleh gak? (contoh 13)

$\mathrm{S}:$ boleh

Selanjutnya guru pemula kembali memberikan contoh menggunakan persamaan linear satu variabel yaitu $\left\{\begin{array}{c}x=2 \\ 3 x=6\end{array}\right.$. Contoh ini sama seperti contoh sebelumnya, guru pemula memunculkan secara langsung tanpa ada pertanyaan siswa. Contoh ini juga bertujuan mengonfirmasi pemahaman siswa tentang subtitusi ketika menggunakan sistem persamaan variabelnya, contoh ini melalui proses ilustrasi dan proses klarifikasi. Proses ilustrasi ketika guru pemula memberikan sistem persamaan linear satu variabel dan menggunakan proses klarifikasi ketika memberikan contoh penyelesaian sistem persamaan linear satu variabel dengan metode subtitusi. Siswa mengetahui subtitusi diartikan sebagai menggantikan, namun siswa bingung apa yang akan digantikan, oleh karena itu guru pemula mengulang contoh spontan untuk metode subtitusi sebanyak tiga kali.

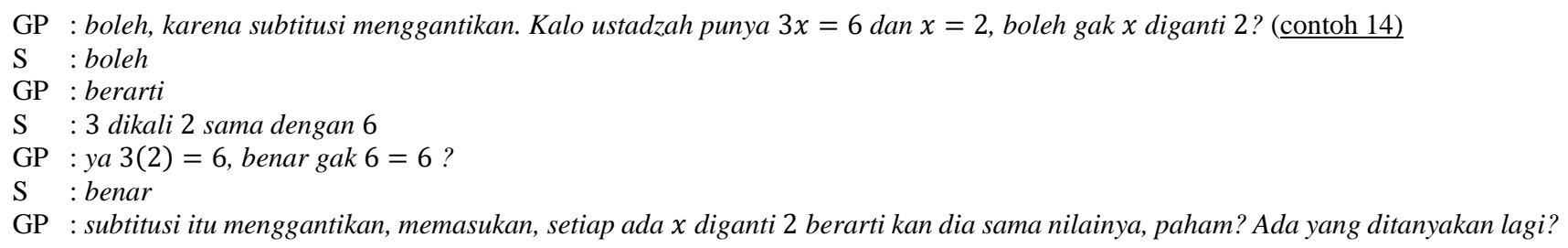

Pembahasan latihan selanjutnya, guru pemula dan siswa mengerjakan $\frac{2}{3} m+m=35.000$ dengan hasil $\frac{5}{3}=$ 35.000, namun ada siswa yaitu S12 yang tidak paham dalam operasi pecahan tersebut. S12 bertanya 5 pada $\frac{5}{3}$ darimana? Guru pemula menjelaskan koefisien 1 pada $m$ disamakan penyebutnya dengan koefisien $m$ yang pertama $\frac{2}{3}$ dan menghasilkan $\frac{2}{3} m+$ $\frac{3}{3} m=\frac{5}{3}$. Kemudian guru pemula memberikan pertanyaan pada $S 12$, pertanyaan tersebut merupakan contoh spontan yang diberikan guru. Guru pemula meminta untuk mengganti penyebut yang awalnya 3 yaitu $\frac{2}{3} m+m=35.000$ menjadi 5 yaitu $\frac{2}{5} m+$ $m=35.000$, S12 merespon dengan benar contoh spontan yang diberikan guru pemula. Contoh ini merupakan contoh yang menggunakan proses ilustrasi, contoh tambahan yang guru pemula berikan tidak jauh berbeda dengan yang menjadi kesulitan siswa. Pertimbangan guru pemula menggunakan contoh dengan menyebutkan penyebutnya sama dengan 5 dalam persamaan $\frac{2}{3} m+m=35.000$ adalah untuk mengingatkan kembali yang telah didapatkan siswa di SD yaitu operasi pecahan. Berikut pemaparan percakapannya. 


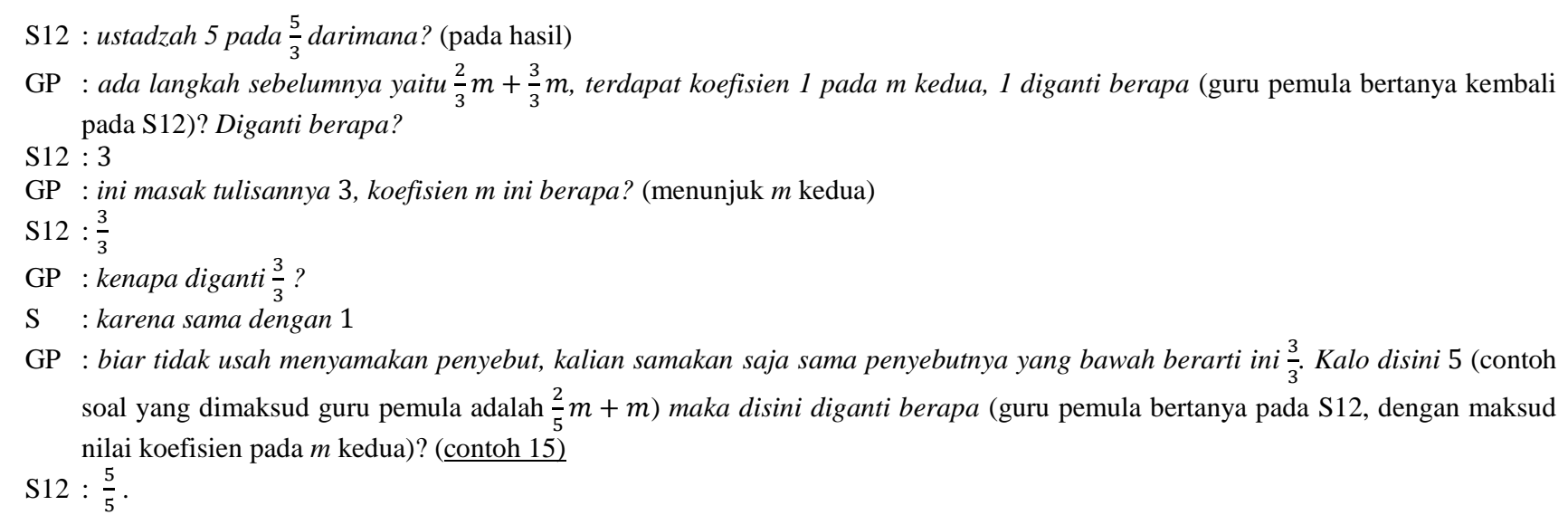

Pada latihan selanjutnya siswa (S13) bertanya tentang koefisien. Guru pemula meminta S13 mengingat kembali apa itu koefisien yang pernah dipelajari di kelas 7, karena S13 tidak merespon guru langsung memberikan pertanyaan yang merupakan contoh spontan. Contoh tersebut yaitu $3 x$ koefisennya berapa? setelah siswa merespon dengan benar guru kemudian bertanya lagi 2y koefisiennya berapa? Siswa juga merespon dengan benar. Pertimbangan pemberian contoh dengan menyebutkan bentuk aljabar suku satu $3 x, 2 y$ adalah sebagai pengingat siswa tentang koefisien. Setelah S13 mampu menjawab dengan benar, guru pemula meminta S13 menyimpulkan sendiri apa itu koefisien berdasarkan dua contoh yang telah dijawab dengan benar sebelumnya. Ini merupakan contoh yang menggunakan proses ilustrasi, guru pemula menggunakan aljabar suku satu untuk mengingatkan siswa tentang koefisien. Berikut pemaparan percakapan S13 dengan guru pemula.

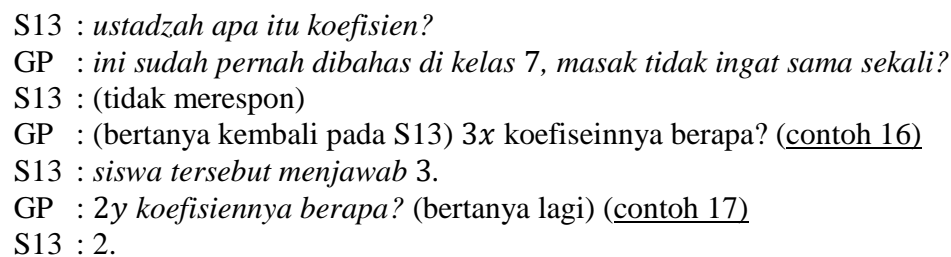

\section{PEMBAHASAN}

Kemunculan contoh spontan yang diakibatkan kesalahan siswa mendominasi alasan pemberian contoh oleh guru, namun terdapat juga alasan pemberian contoh spontan yang berasal dari guru sendiri. Kemunculan contoh spontan oleh guru selanjutnya akan dikarakterisasikan menjadi contoh spontan ilustratif, contoh spontan klarifikatif dan contoh spontan konfirmatif. Berikut akan dideskripsikan kemunculan contoh spontan berdasarkan karakteristiknya.

\section{Contoh Spontan Ilustratif}

Termasuk sebagai karakterisasi contoh spontan ilustratif karena dalam proses kemunculannya guru melalui atau menggunakan ilustrasi dengan contoh spontan tersebut. Contoh spontan ilustratif diberikan guru akibat dari siswa yang bertanya karena mengalami kesalahan, juga saat guru memberikan pembahasan baru. Dengan tujuan siswa tidak akan mengulangi lagi pertanyaan atas kesalahannya dalam memahami konsep ataupun prosedural dan sebagai alat bantu guru dalam menjelaskan materi pada siswanya. Seperti saat siswa bertanya karena bingung dalam memisalkan nilai pada variabel untuk menentukan letak titik potong pada sumbu koordinat, siswa mengalami kesalahan konsep. Guru langsung merespons siswa dengan mengilustrasikan persamaan linear yang lebih sederhana dari pada contoh sebelumnya. Karena Zaslavsky (2010) mengungkapkan contoh harus dibuat relatif mudah untuk membuat siswa tertarik terhadap contoh tersebut. Selanjutnya pemberian contoh spontan diakibatkan siswa yang bertanya tentang operasi penjumlahan pecahan. Hal ini terjadi karena siswa tidak mau memanggil kembali ingatannya tentang konsep pecahan, karena hubungan sangat erat antara pengetahuan konsep pecahan dan pengetahuan tentang prosedur pecahan (Bailey, 2015). Sehingga guru merespons dengan singkat untuk menjelaskan kembali langkah penyelesaiannya, kemudian memberikan pertanyaan berupa contoh spontan sebagai penjelasan tambahan. Guru mengilustrasikan kembali soal berdasarkan latihan dan pada tahap prosedur penyelesaian yang ditanyakan oleh siswa, siswapun dapat menjawab dengan benar.

Kemunculan contoh spontan selanjutnya berbeda karena tidak diakibatkan oleh kesalahan siswa. Guru memberikan contoh langsung ketika siswa diberikan latihan yang ada di buku siswa, ini karena guru menganggap bahwa dalam sub bab yang sedang dijelaskan pada siswa belum membahas tentang soal cerita. Sehingga secara langsung guru mengilustrasikan soal pada latihan, contoh spontan tersebut berupa contoh soal cerita yang kontekstual, agar siswa memahami cara mengubah soal cerita menjadi model matematikanya sesuai dengan latihan. Penggunaan soal cerita kontekstual dapat memudahkan siswa mengenali masalah sebelum memecahkannya (Mardayanti, 2016) dengan masalah kontekstual juga dapat memberikan pengalaman belajar 
yang bermakna bagi siswa dan termotivasi untuk belajar (Trisilahayati, 2017). Guru mengulang kembali memberikan contoh spontan yang berbeda tanpa adanya kesulitan dari siswa, ketika guru menyampaikan pembahasan baru dalam mengajar. Contoh yang dimunculkan oleh guru juga merupakan contoh yang sederhana, agar siswa dapat dengan mudah memahami metode subtitusi. Dari contoh tersebut guru mengilustrasikan dan mengenalkan pada siswa tentang metode subtitusi.

\section{Contoh Spontan Klarifikatif}

Termasuk sebagai karakterisasi contoh spontan klarifikatif karena dalam proses kemunculannya guru melakukan klarifikasi dengan contoh spontan tersebut. Contoh spontan klarifikatif diberikan guru akibat dari siswa menyampaikan pertanyaan atas pemahamannya, kesalahan procedural siswa dalam menyelesaikan soal latihan, siswa yang bertanya karena mengalami ketidakpahaman, dan kesalahan siswa dalam menjawab pertanyaan guru. Dalam pembelajaran yang terjadi, siswa menyampaikan pertanyaan untuk meyakinkan pemahamannya sehingga siswa tersebut mengalami kesalahan konsep. Kemudian guru secara langsung merespons jawaban siswa dengan memberikan contoh spontan, contoh spontan tersebut mengklarifikasi dengan menjelaskan kembali masalah yang dialami siswa, tentang ketidakyakinannya dalam pemahaman yang diterima. Sehingga dengan contoh yang diberikan guru tersebut membuat siswa lebih yakin dengan pemahamannya yang sudah benar. Selanjutnya ketika siswa mengalami kesalahan prosedural, dalam menentukan nilai variabel. Guru memberikan respons dengan contoh langsung untuk mengklarifikasi konsep yang berkaitan dengan kesalahan siswa dalam menentukan nilai variabel. Respons guru juga sama dengan memberikan contoh spontan untuk mengklarifikasi ketika siswa mengalami ketidakpahaman dalam tahapan metode eliminasi, yaitu tidak paham bagaimana cara mengeliminasi variabel yang sudah memiliki koefisien sama sehingga siswa tersebut bertanya pada guru. Kemunculan contoh spontan oleh guru ketika siswa mengalami salah dalam menjawab pertanyaan guru, guru bertanya untuk menjadikan positif pada variabel yang bernilai negatif harus dilakukan operasi kali dengan bilangan apa, dari siswa menjawab negatif 1 dan negatif dari variabel tersebut. Dari dua jawaban siswa yang ada, guru langsung melakukan operasi kali, untuk mengklarifikasi terjadi perbedaan hasil ketika dikalikan dengan jawaban siswa.

\section{Contoh Spontan Konfirmatif}

Termasuk sebagai karakterisasi contoh spontan konfirmatif karena dalam proses kemunculannya guru melakukan konfirmasi, atau menggunakan proses yang melalui ilustrasi dan proses klarifikasi dalam memberikan contoh. Contoh spontan konfirmatif diberikan guru akibat dari siswa menyampaikan pertanyaan atas pemahamannya, siswa yang bertanya, dan tidak ada siswa yang bertanya setelah guru memberikan penjelasan. Dalam pembelajaran tidak ada siswa yang bertanya ketika guru menjelaskan di papan tulis sehingga untuk memastikan pemahaman siswanya guru memberikan contoh. Contoh yang diberikan guru untuk mengonfirmasi bahwa siswanya tidak bertanya karena memang benar sudah paham atau bingung sehingga tidak tahu apa yang akan ditanyakan. Dari pemberian contoh tersebut, ada respons dari siswa untuk meyakinkan kembali pemahamannya tentang materi yang disampaikan guru, dari contoh tersebut guru dapat mengetahui ternyata siswa masih ragu dalam memahami konsep. Selanjutnya, kemunculan contoh spontan guru ketika siswa bertanya. Guru langsung memberikan respons dengan contoh spontan yang melalui proses ilustrasi dan proses klarifikasi, proses ilustrasi dilakukan guru saat membuat contoh baru sesuai dengan kesalahan yang dilakukan siswa, yang dilanjutkan dengan proses klarifikasi untuk menjelaskan pada siswa metode penyelesaiannya. Contoh ini berulang dilakukan guru sebanyak tiga kali.

Alasan guru memberikan contoh spontan ketika siswa tidak merespons apapun atau siswa tersebut tidak mengalami kesulitan. Untuk meyakinkan diri sendiri bahwa siswa sudah paham dengan contoh yang ada di buku ataupun penjelasan guru. Kekhawatiran guru jika hanya dijelaskan dengan contoh yang ada di buku, yaitu ketika membahas bersama contoh tersebut, siswa akan merespons setiap langkah pada penyelesaian di papan tulis berdasarkan penyelesaian yang sudah ada di buku. Guru tidak tahu bahwa siswa tersebut sudah paham atau belum sehingga pemberian contoh spontan menjadi alat untuk guru mengetahui seberapa jauh siswa paham dan seberapa mengertinya siswa tentang materi yang disampaikan guru. Terkadang guru lupa dengan contoh yang sudah dipersiapkan sehingga muncul contoh spontan untuk memberikan penjelasan pada siswa tentang materi baru yang akan diajarkan. Kemunculan contoh spontan dalam pembelajaran mengartikan bahwa guru tidak mempersiapkan contoh tersebut atau tidak ada dalam buku pegangan siswa. Guru mengungkapkan ketika harus mengikuti baku yang ada di RPP, maka guru tidak akan fleksibel dalam merespons kondisi ketika ada masalah yang dihadapi siswa. Untuk merespons kondisi siswa tersebut guru mencoba menghubungkan masalah yang dihadapi siswa dengan pengetahuannya, sehingga muncullah contohcontoh spontan tersebut.

\section{SIMPULAN}

Hasil penelitian ini menunjukan karakterisasi contoh spontan yang diberikan guru pemula yaitu contoh spontan ilustratif, contoh spontan klarifikatif dan contoh spontan konfirmatif Contoh spontan ilustratif adalah proses pembentukan contoh spontan oleh guru yang melalui atau menggunakan ilustrasi dalam contoh spontan tersebut. Contoh spontan klarifikatif adalah proses pembentukan contoh spontan oleh guru yang melakukan klarifikasi dengan contoh spontan tersebut. Contoh spontan konfirmatif adalah proses pembentukan contoh spontan oleh guru yang melakukan konfirmasi dengan contoh spontan tersebut, atau menggunakan proses yang melalui proses ilustrasi dan proses klarifikasi dalam memberikan contoh. Contoh spontan ilustratif diberikan guru pemula untuk mengilustrasikan masalah kesulitan yang dialami siswa dan mengilustrasikan materi baru yang akan 
dijelaskan. Contoh spontan klarifikatif diberikan guru pemula untuk mengklarifikasi kesalahan dan kesulitan siswa. Contoh spontan konfirmatif guru pemula untuk menegaskan konsep matematika pada siswa, dan mengonfirmasi pemahaman materi siswa.

Hasil penelitian ini menunjukan bahwa karakterisasi contoh spontan guru dalam pembelajaran SPLDV yaitu contoh spontan ilustratif, contoh spontan klarifikatif, dan contoh spontan konfirmatif. Disarankan pada guru untuk menggunakan contoh spontan ilustratif ketika siswa memberi pernyataan untuk memastikan pemahamannya, siswa bertanya karena tidak memahami konsep, dan ketika guru memberikan pembahasan baru. Contoh spontan klarifikatif dapat guru berikan ketika siswa bertanya untuk memastikan pemahamannya, kesalahan siswa dalam menjawab pertanyaan guru, dan ketika siswa bertanya karena tidak memahami konsep. Contoh spontan konfirmatif dapat guru berikan ketika tidak ada siswa yang bertanya setelah guru memberikan penjelasan, siswa bertanya untuk memastikan pemahamannya, dan siswa bertanya karena tidak memahami konsep.

\section{DAFTAR RUJUKAN}

Atkinson, R. K., Derry, S.J., Renkl, A., \& Wortham, D. (2000). Learning from Examples: Instructional Principles from the Worked Examples Research. Review of Educational Research, 70(2), 181-214.

Baharullah., Purwanto., Subanji., \& Irawan, E. B. (2016). The Formation of Spontaneous Example by Novice Teacher and Experienced Teachers in the Practice of Mathematics Learning. IOSR Journal of Research \& Method in Education, 6(5), $52-59$.

Bayley, D. (2015). Development of Fraction Concepts and Procedures in U.S. and Chinese Children. Journal of Experimental Child Psychology, (129), 68-83.

Herutomo, R. A., \& Saputro, E. M. (2014). Analisis Kesalahan dan Miskonsepsi Siswa Kelas VIII pada Materi Aljabar. Edusentris, Jurnal Ilmu Pendidikan dan Pengajaran, 2(1).

Huang, C. (2017). Teachers' Choice and Use of Examples in Teaching Derivatives. American Journal of Educational Research, $5(11), 1152-1157$.

Lian, L. H., \& Idris, N. (2006). Assessing Algebraic Solving Ability of Form Four Student. International Electronic Journal of Mathematics Education, 1(1), 55-76.

Mardayanti. E., Zulkardi \& Santoso, B. (2016). Pengembangan Soal Open-Ended Menggunakan Konteks Sumatera Selatan Materi Sistem Persamaan Linear Dua Variabel Kelas X SMA. Jurnal Pendidikan Matematika, 1(10).

Mulungye, M., O’Connor, M. \& Ndethiu, S. (2016). Sources of Student Errors and Misconception in Algebra and Effectiveness of Classroom Practice Remediation in Machakos County- Kenya. Journal of Education and Practice, 10(7).

Sitrava, R. T. (2017). Middle Grade Students' Concept Images of Algebraic Concepts. Journal of Education and Learning, 3(6), 299-305.

Trisilahayati. (2017). Penerapan Model Pembelajaran Hands-on pada Materi Statistika untuk Meningkatkan Hasil belajar Siswa Kelas IX-E SMPN 1 Cirebon Tahun Pelajaran 2015/2016. EduMa, 1(6), 52-61.

Weber, K., Porter, M., \& Housman, D. (2011). Worked Example and Concept Example Usage Understanding Mathematical Concepts and Proofs. Mathematical Association of America, 245-252.

Zaslavsky, O. (2010). The Explanatory Power of Examples in Mathematics: Challenges for Teaching. In Stein, M.K., \& Kucan, L.. (Eds.) Instructional Explanations in the Disciplines. Springer, (107-128). DOI 10.1007/978-1-4419-0594-9_8.

Zazkis, R., \& Chernoff, E. J. (2008). What makes a counterexample exemplary?. Education Study Math, 68, $195-208$.

Zodik, I., \& Zaslavsky, O. (2008). Characteristics of Teachers' Choice of Examples in and for the Mathematics Classroom. Educational Studies in Mathematics, 69, 165-182. 